\title{
HAGIWARA SAKUTARÔ, BUDDHIST REALISM, AND THE ESTABLISHMENT OF JAPANESE MODERN POETRY
}

Roberto Pinheiro Machado ${ }^{1}$

Resumo: Este artigo aborda a obra do poeta Hagiwara Sakutarô (1886-1942) a partir de uma perspectiva comparativa que engaja filosofia e literatura. A dimensão filosófica da poesia de Sakutarô é analisada por meio de uma leitura intertextual entre a obra do poeta japonês e a epistemologia budista presente nos textos em sânscrito dos filósofos Dignāga and Dharmakīrti (século V). Essa análise comparativa é efetuada sob a perspectiva da influência do naturalismo europeu no surgimento da poesia japonesa moderna. Demonstrando a possibilidade de um realismo budista que compartilha importantes características estéticas com o naturalismo, o artigo enfatiza a dimensão budista da poesia de Sakutarô, a qual se desvela apesar da rejeição ao budismo operada pelo próprio poeta como passo necessário para o estabelecimento da modernidade nas letras japonesas.

Palavras-chave: Hagiwara Sakutarô, Poesia japonesa, Budismo, Modernidade, Filosofia

Abstract: This article approaches the works of poet Hagiwara Sakutarô (1886-1942) from a comparative perspective that engages philosophy and literature. The philosophical dimension of Sakutarô's poetry is analyzed by means of inter-textual readings that draw on the tradition of Buddhist epistemology and on the texts of logicians Dignāga and Dharmakīrti (5th century). The comparative analysis is considered under the perspective of the influence of Naturalism and the use of description in the emergence of Japanese modern poetry. Pointing to the possibility of a Buddhist realism that shares some common characteristics with Naturalism, the article emphasizes the Buddhist dimension of Sakutarô's poetry, which appears in spite of the poet's turn to Western philosophy (notably

1. Professor do Setor de Japonês, Departamento de Letras Modernas (DLM), Universidade Federal do Rio Grande do Sul (UFRGS), Porto Alegre, Brasil; robertopinheiromachado@live.com 
to Schopenhauer, Nietzsche, and Kant), as well as to his overt rejection of Buddhism as a necessary step to the modernization of the Japanese letters.

Keywords: Hagiwara Sakutarô, Japanese Poetry, Buddhism, Modernity, Philosophy

\title{
Introdution
}

The relation between Buddhism and Japanese poetry has been given scant scholarly attention in the context of Japanese studies. In Emptiness and Temporality: Buddhism and Medieval Japanese Poetics (2008), Esperanza Ramirez-Christensen presents the problem in the following way:

\begin{abstract}
The presence of Buddhist ways of understanding in the very structures and aesthetics of classical Japanese poetry has not, I feel, been adequately appreciated or rigorously examined in Western scholarship, and the situation, oddly enough, is little better in Japanese scholarship. The reason, in the former case, is surely the former dominance in Anglo-American literary studies of the New Criticism, with its proscription, particularly in poetic analysis, of what were considered extraliterary factors, such as biography and philosophy. The Japanese case is more difficult to explain, but it is probably related to the anti-intellectual, intuitionalist orientation of Japanese literary critical writing (as distinct from the philological rigor of Japanese textual studies); in general, modern native scholars of classical poetry take the ubiquity of Buddhist themes and attitudes in premodern literature for granted; an obligatory nod to the idea of impermanence and the practice of medieval reclusion is deemed sufficient to confirm it. (RAMIREZ-CHRISTENSEN 2008: xii)
\end{abstract}

The aim of this essay is to offer a contribution to answering the demand posited by Ramirez-Christensen. My focus, however, will be modern poetry, instead of the classical one. If the lack of critical attention to the relation between Buddhism and poetry is patent in regard to the classical production, this is even more the case with modern works, where the influence of Western philosophy tends to occupy the larger portion of the scholarly consideration.

The focus here will be the Buddhist philosophical dimension present in the works of Hagiwara Sakutarô (1886-1942), a poet who is generally considered the founder of Japanese modern poetry. The analysis that follows is motivated by the fact that Sakutarô himself openly rejected Buddhism as something that, in his view, hindered the modernization of Japanese letters. What will be argued here, then, is the existence of a subliminal mindset informed by Buddhist epistemology underlying some of the poet's most important works. My analytical conclusions will be suggested much in contrary to the author's own publicized intentions and dispositions.

In order to unfold my analysis, I will start by introducing the theme of the emergence of Japanese modern literature, drawing on the work of Japanese critic Karatani Kôjin to present a historicized version of how the idea of modernity came to be understood in Japanese scholarship. With the establishment of modernity in perspective, I will proceed to consider the theme of the Western influence in the emergence of Japanese modern 
poetry, paying special attention to the role of Naturalism in the process. I will argue that in the Japanese adoption of naturalist literary aesthetics the philosophical dimension of the movement, notably its strong reliance on Comtean Positivism, was obliterated by the traditional philosophical mindset that prevailed in Japan. I will then proceed to investigate the core of such philosophical mindset, calling attention to similarities between Naturalism and Buddhist epistemology in terms of their direct grasp of reality and their avowal of the role of description in establishing truth. My next step will be to turn to Sakutarô's poetry. Sakutarô's early textual adoption of a Buddhist epistemological stance will be observed in the poem Jimen no soko no byonin no kao (1917) where the poet's text will be read comparatively with that of Buddhist epistemology. Such intertextual reading will uncover the idea of truth present in Sakutarô's text in a way that will suggest its similarity and compatibility with Buddhist logic. The analysis will then proceed to a setting of the poem in relation to the Twelve-linked Chain of Co-dependent Origination (Sk. dvādaśánga-pratītyasamutpāda, Jp. jûni'in'en 十二因縁), showing that Sakutarô's poem could be read as a metaphor to the Buddhist notion of samsāra (Jp. rin'ne 輪廻).

My final step in the analysis of Sakutarô's philosophical disposition will be to highlight the poet's complex relation to Buddhist thought and to Western philosophy, notably in the poet's engagement with the works of Schopenhauer, Nietzsche, and Kant. In this final step I will suggest that Sakutarô's rejection of Buddhism and concomitant turn towards Western philosophy betrays an internal search for answers that could have be found within the very Buddhist textual tradition. I will conclude by suggesting a similar disposition towards Buddhism and the theme of transcendence in Sakutarô and Karatani.

\section{The Role of Description in Japanese Modern Literature}

One the most influential critical works to examine the fundaments of Japanese literary modernity is Karatani Kôjin's Origins of Modern Japanese Literature (Nihon Kindai Bungaku no Kigen, 1988). Karatani's analysis provides us with an excellent starting point to answer the question the philosophical underpinnings of modern Japanese literature and of Hagiwara Sakutarô's poetry. Karatani perceives the birth of Japanese modernity as intertwined with the appearance of Realism, which in its turn is embedded in what he calls "the discovery of landscape." For Karatani, a crucial moment in the history of the Japanese arts occurs in the third decade of the Meiji period (18681912), when an epistemological turn produces a new way of perceiving the environment and of rendering it in art. The critic defines landscape as follows: 
Landscape is an epistemological constellation, the origins of which were suppressed as soon as it was produced. It is a constellation which appeared in nascent form in a literary trend of realism in the 1890's. (KARATANI 1988: 22)

Landscape is later described by Karatani as the result of an inversion of consciousness, one that brought to the foreground that which normally pertained to the background. The same process is said to have occurred in the West with the transition from landscape painting to medieval painting (28). The inversion implies a transformation of one's mode of perception, resulting in a new semiotic configuration (27). In the case of Japanese art such inversion, or the discovery of landscape, promotes a flight from the transcendental vision of the world to the objectively perceived reality filtrated by the new presence of the subject:

\begin{abstract}
Once a landscape has been established, its origins are repressed from memory. It takes in the appearance of an "object" which has been there, outside us, from the start. An "object," however, can only be constituted within a landscape. The same may be said of the "subject," or self. The philosophical standpoint which distinguishes between subject and object came into existence within what I refer to as "landscape." Rather than existing prior to landscape, subject and object emerge from it. (34)
\end{abstract}

Landscape is thus as sort of ground to the emergence of the modern subject, or more precisely, the locus for the epistemological fissure that divides reality between the modern self and its other. This emergence of the self is the real epistemological turn that, according to Karatani's analysis, sets modern Japanese literature in motion. Before that, something such as "landscape," together with the descriptive technique that renders it, simply did not exist:

In sansuiga the painter is not looking at an object but envisioning the transcendental. Similarly, poets like Bashō and Sanetomo were not looking at "landscapes." As Yanagita Kunio has said, there is not a single line of description in Bashō's Oku no hosomichi (Narrow road to the deep north, 1694). Even what looks like description is not. (21)

Karatani establishes a relation of virtual identity between landscape, realism, description, and modernity. His assertion that "realism in modern literature established itself within the context of landscapes" (29), suggests the compartmentalization of a larger process. According to the critic, in Japan, just as in the West, the birth of description (or the adoption of realism, or still the discovery of landscape) did away with the transcendental vision of reality that dominated the arts in a premodern, dark, and subjectless age. The Western establishment of modernity was thus just repeated in Japan at a later point in time, namely somewhere in the third decade of the Meiji era. 
I would argue that Karatani's transposition of the Western concept of modernity to Japan fails to recognize important dissimilarities and incommensurabilities. What is implied in the overcoming of the transcendental suggested by Karatani is obviously the downplay of a religious worldview that prevailed in pre-modern times in favor of a new humanistic stance centered in the individual self and informing the new modernity, of which literary realism is an expression. While such overcoming is generally agreed to have occurred in Western history, the same can hardly be said to have happened also in Japan. The absence of a transcendental religious worldview similar to the one upheld by Christianity in the West reveals Karatani's claim regarding the overcoming of transcendence and the concomitant birth of description in Japan during Meiji as the product of a long stretch. What transcendence was overcome in Japan becomes the question immediately begged. If we concede to Buddhism the role of informing an important part of the Japanese pre-Meiji worldview, then we must qualify our assertions regarding the existence of a transcendental realm that could be overcome towards a Western model of modernity in Japan. Although transcendental realms have been posited by some schools of Japanese Buddhism, especially by sects such as Pure Land and Nichiren, to avow the presence of an overarching transcendental Buddhist idea informing Japanese arts and literature all over the pre-Meiji era would be, again, the product of a long stretch. Such claim would imply the deflation of the role in Japanese culture of those Buddhist schools that, contrarily to Pure Land and Nichiren, posited immediate experience and direct perception as the main underlying principle of aesthetic production, and not the search for any sort of after-life paradise. Much less the Shintô dimension of Japanese religion could be construed as positing a transcendental realm prone to be overcome during Meiji by Realism, description or landscape.

In spite of the diverse readings of Buddhist doctrine produced by the different Buddhist sects established in Japan throughout its history, together with their accompanying greater or lesser capacity to create transcendental realms for their partisans (usually in accordance with their greater or lesser tendency to offer popularized versions of philosophical/doctrinal material), it is fairly accurate to say that what took root in the arts and in the general intellectual make up of the Japanese was primarily the Mahāyāna tradition in its Chan/Zen format imported by Eisai (1141-1215) and Dōgen (1200-1253) from China in the late Heian and early Kamakura periods.

Undoubtedly the role of Bodhidharma's tradition in the establishment of the Japanese classical arts needs not be disputed; one only has to think of the Rinzai monks, Sen no Rikyū (1522-1591), Sesshū (1420-1506), and so on. ${ }^{2}$ Deep rooted in the Mahāyāna worldview, Japanese classical arts favored presence and immediate

2. Sen no Rikyū (千利休, 522-1591) had a profound influence in the art of the tea ceremony, establishing the style of wabi-cha, that valued simplicity, directness, and honesty in performance. Sesshū (雪舟, 1420-1506) was the most prominent master of ink and wash painting during the Muromachi period (1336-1573). Both were closely related to the Rinzai (臨済) Zen tradition brought to Japan from China in the early Kamakura period (1185-1333) by monk Myōan Eisai (明菴栄西, 1141-1215). 
experience over transcendence and eschatology. Japanese aesthetic and philosophical concepts, such as mono no aware and mujô, translate Buddhist notions found in Sanskrit sūtra and abhidharma texts (in this case $d u k k h a$ and anitya, respectively). In sum, while Mahāyāna philosophy, with its ideal of the boddhisattva, poses the perfecting of reality (prajñaparāmitā), and as such the attainment of nirvana, in the realm of everyday experienced phenomena, the transcendental that Karatani sees in sansuiga must be understood as something at least very different from the sort of god-centered religious realm that was overcome together with the Western discovery of landscape during the transition from the European middle ages to modernity. It thus becomes clear that Japan could not have made that same movement sometime in the third decade of Meiji.

In spite of this problematic linkage between the discovery of landscape, or the adoption of realism, and a pre-modern transcendental realm that is surpassed towards modernity, Karatani's analysis brings us closer to the important question of how can a direct experience of reality come into being through the modern literary text. Using Karatani's own words, "realism in modern literature established itself within the context of landscapes" (29), and remembering that such realism is rendered through description, the answer to such question must be precisely the latter, that is, description.

Description is that which makes a direct experience of reality come into being through the modern literary text. And description is also that which characterizes the aesthetic mode of Japanese literary modernity started during Meiji. Description, however, is not a product of the overcoming of transcendence. Nor is it in any way contrary to the traditional Buddhist disposition found in the Japanese arts and literature.

Bellow we will look into what Hagiwara Sakutarô has to say about the meaning of poetry and observe how that meaning connects to a notion of truth compatible to the one advanced by Buddhist logic. Before we do that, however, we must review certain aspects of the establishment of Japanese modern poetry, calling special attention to the roles of naturalism and description in its development.

\section{Naturalism and Buddhism in a Syncretic Mode: Description and Truth in Japanese Modern Poetics}

The relation between philosophy and literature has been analyzed in considerable detail by Martha Nussbaum in Love's Knowledge (1990), where the author notes that "literary form is not separable from philosophical content, but is, itself, a part of contentan integral part, then, of the search for and the statement of truth (NUSSBAUM 1990: iii). Nussbaum's perception of literary form as inextricably connected to philosophical truth immediately sets literature in the realm of philosophy; for philosophy must be the sort of inquiry that has truth itself as its primary object. The author's remarks also suggest the possibility of inter-textual reading between literature and philosophy carried out with the search for or the expression of truth as a common and guiding principle. 
Truth itself can be seen as an inter-textual connector between literary and philosophical texts in the context of a comparative approach where philosophy and literature shed light at each other.

We should thus turn to the specifics of poetry and look for a hint to any tangible relation it may have to truth. In her search for the Buddhist dimension of Japanese classical poetry, Ramirez-Christensen discerns the existence of a traditional usage of poetry "understood as the symbolic demonstration of a religious or philosophical system." Here the author proceeds to a definition of what she calls "the poetic process of Zen meditation," where

\begin{abstract}
Poetry is viewed first and foremost as the transformative power of the liberated mind (kokoro 心) to breach the predetermined meanings of the linguistic system, which is the same as to show the ultimate emptiness of the sign, and how it is precisely emptiness that enables the play of language, the infinite possibilities of metaphorization. (RAMIREZCHRISTENSEN 2008: 32)
\end{abstract}

In Ramirez-Christensen's model of Zen poetics, the liberated mind breaches the predetermined meanings of the linguistic system just to go back to a play of language now purified, or enriched, by the infinite possibilities of metaphorization. Metaphor seems to continue after the mind becomes liberated and language appears to remain as the focus of the poetic process. In my view this model turns the entire poetic endeavor into a circular event: the liberated (poetic) mind attempts to break through language just to go back into metaphorical play: language becomes the beginning and the end, and metaphor appears as an end in itself.

Contrarily to Ramirez-Christensen's view, I argue that the gist of Zen poetics lies not in free metaphorization, but in breaking with predetermined linguistic meanings with the intent of arriving at a consolidated expression of truth that is at the same time the product of a direct experience of reality as well as poetic form achieved through linguistic description. While Ramirez-Christensen seems to understand the poetic process of Zen meditation in terms of Zen kôans or similar linguistic products based on free metaphorizations, I consider the same poetic process in terms of the haiku of poets such as Bashô and Buson. I believe that the direct experience of reality established in the haiku format configures the quintessential poetic expression of truth achieved by means of literary description and Zen meditation.

Many philosophies have supported the role of description as a means of access to reality as such, or to the establishment of truth in linguistic terms. Even mutually disparaging philosophies such as Phenomenology and Positivism have argued for description's power in rendering real experience. While the Husserlian phenomenological-descriptive method is thought to have influence the birth of literary instances such as the French nouveau roman, Positivism, with its emphasis on direct observation and empiricism, can be said to have provided an epistemological ground 
to the development of Naturalism. With this in mind, it is clear that description as such does not pertain exclusively to any philosophical school.

Buddhist philosophy in particular, with its epistemology based on direct perception and immediate experience, is also compatible with the descriptive mode in literature. Turning to the history of Japanese poetry, we can suggest how the descriptive mode of Western modernity was reinterpreted in Japan and subsumed under a Buddhist epistemology.

Modern descriptive literary technique made its way into Japanese poetry by means of two major events that occurred at the end of the nineteenth century: the development of the genbun-itchi movement, and the establishment of shintaishi, or new style poetry. The first proposed the unification of written and spoken language, and the second started a revolution of poetic aesthetics through the influence of translated Western verse.

The role of genbun-itchi in the creation of Japanese modern poetry was first observed in 1906 by the influential critic Shimamura Hôgetsu (1871-1918). In an article published in the June issue of the magazine Bunsho Sekai (The Literary World), entitled "Isseki bunwa" (One Night's Conversation), Hôgetsu proceeded to a defense of the genbun-itchi's proposal for the creation of a colloquial literary style in Japan, and predicted its future adoption in modern Japanese poetry (TOMASI 2007: 122). ${ }^{3}$ The genbun-itchi is closely connected to the rise of Naturalism in Japan, another movement fully endorsed by Hôgetsu. As Massimiliano Tomasi remarks,

\begin{abstract}
Following the appearance of Shimazaki Tōson's novel Hakai 破壊 (The Broken Commandment) in 1906, Hōgetsu declared his full support for this literary school, writing a number of consequential articles that gave momentum to the rise of the movement. This surge of a strong naturalist trend touched all areas of literature. Naturalism's denunciation of traditional literary conventions and its call for a plain and direct mode of expression found fertile ground in the realm of poetry where such a call soon came to signify the rejection of a fixed meter and the employment of poetic expressions that were the result of the poet's own creation rather then a recycling from the conventional poetic canon. Its call for objectivity and for a direct connection to reality and one's environment also had a vital influence on poets and their poetic production. (125)
\end{abstract}

What interests us here is to note that Naturalism's call for a direct connection with reality, which was aptly noted by Tomasi, makes it primarily compatible with Buddhist epistemology and its emphasis on direct perception (of which more bellow). We should remark, furthermore, that from a philosophical standpoint Japanese Naturalism differs substantially from its European counterpart. Although in both movements the call for objectivity is a mutually shared principle, European

3. This appears in the section of Hôgetsu's article entitled "Genbun itchi to shōrai no shi" (Genbun-itchi and the poetry of the future). 
Naturalism's objectivity carries a heavy connotation of Comtean Positivism, which is virtually absent from the Japanese movement. Let us then look more closely to the positivistic dimension of European Naturalism.

The theme of Naturalism as a world literary phenomenon has been examined by Christopher Hill, who observes the distinct patterns of circulation by means of which the movement emerged in Latin America and in Asia. The Brazilian and Argentine movements appeared through contact with French currents, but also by means of the works of Spanish writers, such as Benito Pérez Galdós and Emilia Pardo Bazán, in the case of Argentina, and Portuguese ones, such as José Maria de Eça de Queirós, in the case of Brazil. As Hill notes, that itself accounts for a significant difference between the European and the Latin American movements (HILL 2009: 1199).

In the case of East Asia, the path of circulation would involve both a direct implication with France as well as a detour through English. The fact that Shimazaki Tôson (1872-1943), the central figure in the origin of Japanese Naturalism, was fluent in English and learned French only later in his life suggests the role of the English language, and of translation, in the transmission of Naturalism to Japan. ${ }^{4}$ The arrival of the movement in East Asia thus started with Japan; Naturalism was subsequently transmitted from Japan to China and to Korea (1205).

Such distinct patterns of circulation suggest the possibility of distinct philosophical contexts in which the movement was received starting in the second half of nineteenth century. It is generally agreed that the Positivism of Auguste Comte (1798-1857) constitutes the major philosophical component of literary Naturalism. Regarded as the founder of the discipline of sociology, Comte's influence on nineteenth century France was far ranging, and it is not inaccurate to say that Émile Zola (1840-1902) became his major literary voice. Naturalism's attempt to apply scientific principles of objectivity to the study of human behavior repeats Positivism's defense of empiricism and rationality as the correct way to approach reality.

As we have seen from Tomasi's abovementioned fragment, Naturalism played a major role in the rejection of fixed meter that came to signify the transition from the classical poetic form in Japan to the free-style colloquial verse that, we should remark, was established by Hagiwara Sakutarô in his 1917 Howling to the Moon. With this in mind, it becomes evident that Naturalism must have exerted a major influence on Sakutarô, just as, by symmetry, must have Positivism. However, this logic seems to have been broken at some point. In order to perceive where Positivism failed to make its way into Sakutarô's poetry, we must look into the reception of Positivism in Japan in more general terms.

4. Tôson's relation to the English language is an important aspect of his professional and intellectual development, as well of the establishment of Naturalism in Japan. The author started his professional career as a professor of English at Meiji Women's School in 1882. For a discussion of Tôson's relation to the French language please refer to William E. Naff's The Kiso Road: The Life and Times of Shimazaki Tōson (University of Hawaii Press, 2011), pp. 351-359. 
It is in the domain of the novel that the complex question of the adoption of Naturalism/Positivism in the Japanese letters becomes more evident. Although a close comparative reading of the Japanese and the European Naturalist movements is beyond the scope of this article, a brief look at Shimazaki Tôson's Hakai (1906) and Émile Zola's Germinal (1885), two novels that are generally regarded as the masterpieces of the genre in Japan and in Europe, will show us remarkable differences in philosophical content that are highly pertinent to our inquiry. Perhaps the most important difference involves the question of determinism, which is one of the major tenets of Comte's philosophy. Although some level of social determinism is undeniably present in Hakai, especially in the portrayal of the condition of the shinheimin, ${ }^{5}$ Tôson's protagonist's flight to America at the end of the book stands for the very possibility of overcoming such determinism. Although it could be argued that Zola's Germinal ends in a similar optimistic note, this time with a heavy socialist utopian connotation, it is clear that in Zola's novel, Étienne Lantier's capacity to transcend his social determinisms does not shoulder that of Tôson's Ushimatsu.

If in Hakai's social determinism is subdued in comparison to Germinal, its portrayal of genetic determinism is virtually non-existent: although Tôson engages in some fairly cruel descriptions of the shinheimin as doomed to a lowly existence, Ushimatsu is never a heir to the shinheimin's shorcomings. Nothing in his physique or intellectual make up betrays any kind of lowly origin. In Germinal, on the contrary, Zola's genetic theories come into play with full force as Étienne Lantier is described as having inherited his ancestors' traits, which include, for instance, a drinking habit usually followed by fits of rage.

My point with this all too brief analysis is that such differences in content are not only fundamental to the perception of the philosophical dimension of Japanese Naturalism, but above all to the understanding of the originality of the Japanese movement. Such originality can be more fully appreciated through a comparison between the Naturalist novel in Japan and in Latin America, another area involved in the circulation of Naturalism and its philosophical principles. Here again limitations of space constrain us to a few brief remarks, which, however, should help us clarify the question of the relation between philosophical Positivism and Naturalism in Japan. Through the following we should notice the much stronger presence of Positivist ideology in Latin America as an indicator of the Japanese selective adoption of the genre at the level of philosophical content.

Still in regard to the theme of determinism, the novels of Mexican Federico Gamboa (1864-1939) and Brazilian Aluísio Azevedo (1857-1913), while setting the ground for the rise of Naturalism in their countries, presented characters that repeated faithfully Zola's positivist philosophy of existential atavism. Such is the case of Aluísio

5. The word shinheimin (新平民) translates as "new commoner," and refers to the new social status assumed by former outcastes as the caste system was abolished in Japan in the early Meiji period. Tôson's Hakai approaches this theme from the perspective of literary Naturalism. 
Azevedo's $O$ mulato (1881), where the mixed race protagonist Raimundo returns to his hometown unaware of his origin as the son of a black slave woman just to find his demise without ever being capable of transcending his racial condition. The same sort of deterministic fate runs throughout Federico Gamboa's Santa (1903), where the condition of poverty leads the main character into prostitution and ruination, a theme already present in Stephen Crane's novel Maggie: A Girl of the Streets (1893), a work generally considered to be the cornerstone of American naturalism.

Another, and actually stronger, indicator of the remarkable difference between the Latin American and the Japanese adoption of Comtean positivism can be seen in the more general field of national political thought. Here we can observe that while in Latin America the political and the literary went hand in hand in regard to the philosophy that underlies literary Naturalism, the same did not occur in Japan.

In the political domain, Positivism defended the establishment of a republican dictatorship as the most adequate form of government, an ideological trend that took hold in Mexico together with the rise of the naturalist novel. Here the rise of positivistic republicanism and the emergence of the naturalist novel appear as two facets of the same movement. Positivism was in fact the main ideology supported by Mexican dictator Porfírio Díaz (1830-1915), who ruled the country for over thirty years until 1911. Díaz favored all forms of scientificism in Mexican society, and established around himself a clique of politicians and intellectuals that he called "científicos." Among them appeared the diplomat and novelist Federico Gamboa, the same who authored the aforementioned novel Santa.

A republican dictatorship was the way towards which Brazilian politics was developing around the same time. Here the fall of the monarchy in 1889 brought something similar to a military dictatorship with the first two presidents being high military commanders and fierce defenders of Positivism. On the literary side, Brazil's main naturalist novelist, Aluísio Azevedo, worked also as journalist and published harsh critics of the emperor, Peter II, calling for the establishment of a republic. So just as in Mexico, the republican ideal of Comtean positivism permeated the political and the literary in Brazil. Brazil's Positivism was so strong that to this day the Brazilian republican flag shows the positivist slogan, "order and progress."

A contrary movement from that of Mexico and Brazil occurred in Japanese politics at the time of the rise of Naturalism. While the two Latin American countries maintained the authoritarian republican ideal of the positivist credo, Japan was precisely leaving the military dictatorship of the Tokugawa Shogunate to proceed towards a constitutional monarchy. The direction was precisely the opposite of the one taken by Brazil, specially. Although we cannot engage in an exercise in comparative law and here, an analysis of these countries' constitutional arrangements would disclose the enormous differences in the general intellectual climate of such importers of European Naturalism. For one thing, the Bismarckian nature of the Meiji Constitution went in the opposite direction of the Brazilian Constitution of 1891, which was modeled after that of the United States. While 
the political found a direct parallel in the literary, and while the political engagements of Federico Gamboa and Aluísio Azevedo clearly demonstrated an overt adoption of the positivist agenda, just the opposite was the case with Shimazaki Tôson, whose approach to naturalist aesthetics set the general mode of Japanese obliviousness to Comtean Positivism.

The parallel progression of the political and the literary in Latin America's adoption of Naturalism and Positivism, when seen in comparison with the contrasting case of Japan, suggests the latter's resistance to a foreign philosophy as compromising as Positivism. Above all, it suggests Japan's selective approach to Naturalism, one that, I will argue, was carried over from the domain of the novel to that of poetry. Before we enter this latter domain, however, it is important to summarize with the remark that by looking to the specifics of Japanese Naturalism in its relation to Positivism, the notion of Japan's epistemological turn at the dawn of Meiji, suggested together with a discovery of landscape and an establishment of the modern subject, calls for qualification.

We thus encounter our next question: if Positivism was not fully absorbed together with Naturalism, then how could we define the philosophical dimension of Japanese Naturalism?

In order to answer this question we must turn again to the field of epistemology and to the role of description in expressing truth. We have mentioned that many philosophies avowed description as the correct way to access reality, among them mutually disparaging one's such as Phenomenology and Positivism. Now we should observe what Buddhist philosophy has to say about description. This will give us an idea of how to better tackle the philosophical content of Japanese Naturalism.

The Buddhist understanding of description can be observed from the analysis of valid cognition found in Buddhist logic. Developing around the beginning of the fifth century, the school of logic of Dignāga and Dharmakirti established the correct way of approaching reality from sense perception, refining what I call the principle of realism existing in Buddhist philosophy. Dignāga (Jp. Jin'na 陳那, c. 480-540) was a disciple of the Gandharan monk and philosopher Vasubandhu (Jp. Seshin 世親, c. $4^{\text {th }}$ century CE), one of the founders of the Indian Yogācāra school of Buddhist philosophy, also known as the "mind only" school. Vasubandhu is also held as the 21st patriarch of Zen. Dignāga tried to accommodate his master's radical skepticism, summarized in the notion of the emptiness of all dharma, in a system that asserted the validity of knowledge. Dignāga's claim was that albeit existing primarily in the mind, knowledge held a truthful correlation with the exterior world.

The Sumatran scholar and philosopher Dharmakīti (Jp. Hosshô 法称, c. 7th century) expanded on Dignāga's work and wrote most of his famous Seven Treatises on Valid Cognition in the form of commentaries on the latter's texts. Together, the logicians advanced a new form of deductive reasoning and built a rich and complex sub-system of Buddhist philosophy that overshadows much Western work on logic and epistemology.

Buddhist logic came to be known in the West initially through the works of Russian 
indologist F. Th. Stcherbatsky (1866-1942), who in his foundational work Buddhist Logic (1930) writes:

\begin{abstract}
[The system of Buddhist logic] claims to be the natural and general logic of the human understanding (laukika-vidya). However, it claims also to be critical. Entities whose existence is not sufficiently warranted by the laws of logic are mercilessly repudiated, and in this point Buddhist logic only keeps faithful to the ideas with which Buddhism started. It then denied a God, it denied the Soul, it denied Eternity. It admitted nothing but the transient flow of evanescent events and their final eternal quiescence in Nirvana. Reality, according to Buddhists, is kinectic, not static, but logic, on the other hand, imagines a reality stabilized in concepts and names. The ultimate aim of Buddhist logic is to explain the relation between a moving reality and the static construction of thought. (STCHERBATSKY 1962: 2)
\end{abstract}

If we agree that Buddhism comprises one of the main intellectual grounds to the Japanese arts and literature, and if, following Stcherbatsky, we recognize Buddhism's fierce philosophical denial of God, of the Soul, and of Eternity, then we must accept that Karatani's abovementioned claim of the emergence of landscape and description in the Japanese arts during Meiji as the overcoming of a transcendental realm does not hold. This point is very important to our analysis, for in the next section we will see how Sakutarô's denial of Buddhism repeats the same misinterpretation of Karatani's in regard to the existence of a transcendental realm that was overcome by Japanese modernity.

From the prism of Buddhist logic we can derive the notion of Buddhist realism, and with it understand the Buddhist avowal of description as a means to express reality. Dharmakīrti was one of the founders of Buddhist atomism, according to which the only objects considered to exist are momentary states of consciousness. Such states, however, must bear a close relation to what appears in the cognitive field as external reality, and thus be capable of leading human beings to the clarity of mind inhering in nirvana. In this sense, Dharmakirti's attempt to determine the correct correlation between the mind and the objects it produces in a succession of momentary states of consciousness holds a close and fundamental relation the Buddhist märga, or path to enlightenment. Such relation was emphasized by Helmut Krasser, who showed the close connection between Dignāga and Dharmakīrti's science of epistemology and logic, or hetuvidyā (Jp. In'myō 因明), and the general Buddhist soteriology. ${ }^{6}$

The Buddhist soteriological dimension of logic produced an epistemology of presence that is reflected in the Japanese classical arts as these advance a definition of

6. In response to allegations that Buddhist logic is primarily unrelated to the soteriology of Buddhism, Helmut Krasser observes that "Dignāga's stated aim in writing his Pramānasamuccayavrtti is to 'establish valid cognition' (pramānasiddhi)" and that "it is clear that in the intention of the promoters of pramanna studies this system [of valid cognition] apparently had a strong connection with Buddhism as a religion, i.e., as the teaching if a path towards salvation, and that they never considered themselves to be involved in non-Buddhistic activities" (Helmut Krasser: Are Buddhist Pramānavādins nonBuddhistic?, in Hōrin: Vergleichende Studien zur japanischen kultur, 11/2004, p. 129 and 146). 
art as experience and as $d \bar{o}$ (道), or as the Way to truth and enlightenment (a notion that, it must be noted, possesses also strong Daoist influence). Looking at Buddhist logic and its assailing realism, the harmonious images of sansuiga perceived by Karatani as depictions of a transcendental realm now appear as portrayals of ultimate reality conceived as the point instant. The clarity of vision presented in the images discloses the contents of a purified mind in its strongest cognitive capacity and amount to a profound depiction of reality in its utmost bareness. The disposition is essentially realist, and essentially Buddhist.

A look into some of Dharmakīrti's analytical concepts will provide us with a clearer notion of what I mean by the concept of Buddhist realism. Buddhist logic is often referred to as Pramāna Theory, indicating an analytical approach to the instruments of knowledge, or pramāna. Since such instruments are listed as perception and cognition, Pramaña Theory amounts to a philosophy of mind based on logic. Such logic reveals the possibility of two forms of valid cognition, one realized through direct perception (pratyakșa) and another resulting from inference (anumāna). It is from Dharmakīrti's analysis of inference that we will perceive the Buddhist avowal of description as a means to access reality as such, disclosing thus the notion of Buddhist realism. Regarding Dharmakīrti's Pramāna Theory, John Dunne writes:

Pramāna Theory generally speak of two forms of inference: "inference for oneself" (svārthānumāna) and "inference-for-others" (parārthānumāna). The former is simply an inferential cognition: one looks at a smoky room, for example, and (with other conditions in place) one infers that fire is present. In contrast, an inference-for-others is one that is stated verbally so as to induce an inferential cognition in another person. In other words, this latter "inference" (which is actually a series of statements and not an inference) is meant to result in another person having his own inference-for-oneself in regard to the question at hand. (DUNNE 2004: 25)

The idea of parārthānumāna clearly amounts to the structuring of a narrative. This series of statements, as far as they are a means of valid cognition, establish reality and truth in a descriptive way not contrary to literary realism. Dunne goes on to explain in detail the basic structure of Dharmakīrtian inference:

$\mathbf{S}$ is $\mathbf{P}$ because $\mathbf{E}$

A typical example if this type of inference is:

The hill (S) is a locus of fire $(\mathbf{P})$ because of the presence of smoke $(\mathbf{E})$.

Here, $\mathbf{S}$ is the "subject," called the sädhyadharmin or pakșa in Sanskrit; $\mathbf{P}$ is the "predicate," known as the sädhyadharma; and $\mathbf{E}$ is the "evidence," know as the hetu or linga. 
Here theinference will be ultimately valid as long as it overcomes conceptualization. Since a concept implies always some level of error or distortion, Dharmakīrti establishes the notion of svabhàvapratibandha, or "necessary relation," as the basis for a valid inference. Such relation must exist between the evidence and the predicate so that the former can be inferred from the latter. A necessary relation is thus defined as one of pervasion (vyāpti), which in the example above indicates the inextricability of fire and smoke. Such inextricability, it should be remarked, is cognized by means of direct perception (pratyakșa), the first pramāna, or means of valid cognition (151).

The extent to which such epistemology permeates Japanese art and literature has been greatly overlooked in Japanese Studies. Let us look at an example from the Kokinwakash $\bar{u}$ 古今和歌集 (c. 920):

\author{
吹くからに \\ 秋の草木の \\ しをるれば \\ むべ山風を \\ 嵐といふらむ \\ Fuku kara ni \\ Aki no kusaki no \\ Shiorureba \\ Mube yamakaze wo \\ Arashi to iu ran
}

Because right after its blow

The autumn grass

Withers completely

The mountain wind

Is called a storm. ${ }^{7}$

This poem by Fun'ya no Yasuhide (b. 885) repeats almost directly Dharmakīrti's syllogism: arashi (嵐), or the storm, is the predicate; yamakaze (山風) or the mountain wind, is the subject; and aki no kusaki (秋の草木), or the (withered) autumn grass, is the

7. All translations from the Japanese are my own unless otherwise noted. 
evidence. The relation between the evidence and the predicate is one of necessity, or one of svabhāvapratibandha. Perhaps a more poetic way to render the piece in translation would be:

\author{
Is it not precisely because right after its blow \\ The autumn grass \\ Withers completely \\ That the mountain wind \\ Is called a tempest?
}

This version would probably be more successful in accounting for the sense of doubt present in the ending to iu ran (といふらむ), but the basic syllogism that lies at the core of the poem would not be altered. What interests us primarily, however, is to notice the superb sense of realism present in the text. Piercing though all the suggestive overtones that make it a sort of aphorism, the clear cut reality on which the poem is based conveys a sense of resoluteness and certainty resonant of the absolute. From its basic expression of truth to a fully developed sense of description is more a matter of length and form than of content.

As nothing like a transcendental realm can be derived from Fun'ya no Yasuhide's poem, we might as well define it aesthetically as a basic form of Japanese realism. As far as it repeats the basic syllogism of Buddhist logic, we might also call it Buddhist realism. This classification certainly gives the lie to the notion that literary realism is exclusively a Western category.

Up to this point we have seen that Dharmakīrti avows two forms of valid cognition: direct perception (pratyakșa) and inference (anumāna). We have also seen how the latter functions as a prototype to realist description. Now we must make a brief return to observe how the first, direct perception, also functions within a realist epistemological stance.

Let us consider the following modern haiku by Fujita Sôshi (1926-2005):

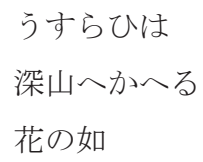


Usurai wa

Miyama e kaeru

Hana no goto

The thin veil of ice

Returns to the mountain recess

Like a bed of flowers

We mentioned above that Buddhist logic considers the ultimately real to exist solely in the point instant. We also remarked that, from its relation to Buddhist atomism, it avowed that the only objects considered to exist are momentary states of consciousness. Now, with the above poem in perspective, we can see how the notion of direct perception also provides a ground to literary realism.

The mental image comprised of the vision of the mountain recess with its veil of ice likened to a bed of flowers produces again reality in its stark bareness. One could say that the whole poem is the result of two pure perceptions linked by a comparison. The simile allows a new element to come into play: the bed flowers. The result is a unity in perception. The entire poem can be read as the statement of a mental image that creates an experience of sheer presence. Here we might link Fujita Sôshi's poetic statement to Dharmakīrti's notion of svalakșana. In regard to this concept, Yoshimizu Chizuko writes:

Little needs to be said about the considerable significance of the term svalaksana which literally means 'own characteristic', and comes down to term for 'particular' or 'individual'. Svalakșana is characterized by Dignāga (6c.) as the object of direct perception (pratyakșa), i.e., the object of a cognition which is free of conceptual construction (kalpanapodha). Dharmakīti added to this epistemological notion a clear ontological ground by identifying it with that which has causal efficacy (arthakriyāsãmarthya, arthakriyāsakti. don byed nus $p a$ ), that is, an ability to produce an effect. (YOSHIMIZU 2004: 118)

In Fujita Sôshi's haiku we encounter the particularity of an event that is complete and self-sufficient, being thus free from conceptual construction in the very sense of Dharmakirti's svalakșana. The percept may liken the veil of ice to a bed of flowers, but the latter is not any sort of quality added to the former. The mental image is, again, clear from conceptualization and essentially realistic, giving us another example of the degree to which Japanese realism is committed to expressing the pure presence of the directly observed, and not any sort of transcendental reality. The self-sufficiency of the real is explained in Dharmakīrti's Pramānavarttika in the following terms: 
(43) ekasyārthasvabhāvasya pratyakṣyasya satạ̣ |

ko 'nyo na dṛșt.o bhāgaḥsyād yạ̣ pramāṇaih. Parikṣyate $\|^{8}$

Satkari Mookerjee and Nagasaki Hojun offer the following translation to Dharmakīrti's karikā (verse):

One objective entity which is directly perceived as it is itself (is perceived in its entirety).

How can it have any part which is not perceived along with it and as such would admit of being examined (and proved) by acts of inference (as separate cognition)? (MOOKERJEE and NAGASAKI 1998: 98)

Mookerjee comments that Dharmakīti's point in this karikā is that "when the subject is known by perception and its whole nature is entirely apprehended by it, the scope of application of another pramanna is ruled out (for the ascertainment of any property connected with it). This simply means that adding predicates to a fully apprehended subject is merely a conceptual construction, and as such does not disclose the real as it is." (99) In Fujita Sôshi's veil of ice and Fun'ya no Yasuhide's mountain wind, the mental picture they amount to is unique, discrete and instantaneous, and as such stands on its own independently of further qualification.

Buddhist logic's pramānas, or means of valid cognition (direct perception and inference) conform the epistemological ground of Buddhist realism. With this in perspective, we are now in a position to return to the descriptive aspect of Naturalism and reappraise the philosophical dimension of Japanese Naturalism.

As we have seen, Japanese Naturalism adopted formal and thematic elements present in the European movement but, contrarily to its Latin American counterpart, avoided an open reception of Positivism at the philosophical level. To suggest the Buddhist dimension of Japanese Naturalism, we should recall that at the dawn of the twentieth century, Shimazaki Tôson opened his novel Hakai, probably the major achievement of Japanese Naturalism in any artistic form, at the gates of the Buddhist temple Renge-ji (蓮花寺), setting up a Buddhist scenario whose significance in the narrative process has been greatly overlooked by critics. This same Naturalism, as we have noted above from Tomasi and Hôgetsu, exerted profound influence on Sakutarô's establishment of free-style colloquial poetry, and with it of Japanese modern poetry. We will now turn to Sakutarô's text and to the inquiry on the Buddhist realist dimension of Japanese kindaishi.

8. Cited from Yūsho Miyasaka ed., Pramānavarttika-karikā, in Acta Indologica, Vol. II, Naritasan Shinshoji, 1972, p. 120. 


\title{
3. Hagiwara Sakutarō, Japanese Modern Poetry, and Buddhist Realism
}

We are now in the position to operate a comparative reading of the texts of early Japanese modern poetry and Buddhist philosophy. We will start by looking at Sakutarō's comprehensive theory of poetry set forth in his Shi no Genri (Principles of Poetry, 1928). Our main interest in this work resides in two specific points: first, Sakutarô's appraisal of Naturalism; and second, his vision of Buddhism.

Regarding the first, I will cite Sakutarô's original text of the preface to the second edition of 1938:

\begin{abstract}
私がこの書を書いたのは、日本の文壇に自然主義が横行して、すべての詩美と詩 的精神を殺翏した時代であった。その頃には、詩壇自身や詩人自身でさえが、文 壇の悪レアリズムや凡庸主義に感染して、詩の本質とすべき高邁性や浪漫性を自 己虐殺し、却って詩を卑俗的デモクラシイに散文化することを主張していた。し たがってこの『詩の原理』は、かかる文壇に対する挑戦であり、併せてまた当時 の詩壇への啓蒙だった。(HAGIWARA 1975: 47)
\end{abstract}

When I first wrote this book, Naturalism was taking hold of the Japanese literary world, and it was a time when poetic beauty and the poetic spirit were being abused and destroyed. At that time, even poetry groups, as well as the poets themselves, were being infected with the evils of bad realism and the banalizing tendencies that were upheld by the literary world at large. So that that which should be poetry's very essence, namely nobleness and romanticism, was being massacred. Even worse, the vulgarization of poetry was being openly demanded by the insistence on its prosification. As such, this Principles of Poetry meant a challenge to the literary world, as well as source of enlightenment to the poetic circles of that time.

Here we see that Sakutarô held Naturalism in very low esteem. We should notice, however, that such opinion was not uncommon in his times. The poet's identification of Naturalism with vulgarity calls to mind once again the Latin American example, where in 1878 Brazilian novelist Machado de Assis wrote harsh critique of Portuguese writer Eça de Queirós, the alleged founder of Portuguese Naturalism. The text is well know in the history of Latin American letters, and the attacks on Naturalist aesthetics, although similar in content to Sakutarô's, are worded in much harsher terms than would be conceivable as issuing from the Japanese poet. ${ }^{9}$

Be it as it may, it is clear that none of the writers perceived the scope of Naturalism's epistemological stance. Sakutarô's equation of Naturalism with vulgarity, together

9. Machado de Assis's text is entitled "O primo Basílio, de Eça de Queirós" (1878) and appears in Obra Completa de Machado de Assis (Rio de Janeiro: Nova Aguilar, vol. III, 1994). The Brazilian writer's almost pathetic revolt against the naturalism of Eça de Queirós is uncalled for in several ways, the most prominent of which being that Eça de Queirós is hardly at all a naturalist. Although esteemed as a major Portuguese writer, his works are more like naïve imitations of nineteenth century European popular romances, rather than serious works of the naturalist school of Zola. 
with his assertion of its ruling out of romanticism and nobleness, seems to overlook the fact that the founder of Japanese Naturalism in the novel, Shimazaki Tôson, was also the introducer of romanticism in poetry with his Wakanash $\hat{u}$ (若菜集, 1897). If nothing else, this could have called for a more qualified appraisal of Zola's aesthetics. In any case, it is worth noting that Sakutarô's evaluation of Naturalism is precisely opposite to the one we saw earlier as espoused by Shimamura Hôgetsu. This suggests not only the polemic and contradictory nature of Naturalism itself, but also Sakutarô's somewhat strict understanding of the movement, together with the poet's inattention to Naturalism's role in the structuring of modern poetry and of his own work.

We may now turn to our second point of interest in Shi no Genri, namely Sakutarô's perception of Buddhism. Moving forward to the fourth chapter of the first part of the book, entitled Chûshôkan'nen to Gushôkan'nen (Abstract Notions and Concrete Notions), we find Sakutarô's general critique of intellectual movements, or "isms," which he perceives as implying some form of idealism. Among such tendencies the poet includes Buddhism, which he uses as an example:

\begin{abstract}
例えば仏陀の幽立な哲学は、一切の価值を否定することに於て、逆に価值の最高 のもの（涅槃）を主張している。そして所謂ニヒリズムは、存在のあらゆる権威 を否定しながら、逆にその虚無に権威を感じ、そこに彼自身のイデヤを見てい る。ダダイズムの如きも「一切の主義を奉じない」と言いながら、その「主義を 奉じない主義」を奉じてる。故に絶対の意味で言えば、世にイデアリズムでない ところの、どんな主義も有り得ない。一切主義であるす心゙てのものは、それ自ら 理想的であり、観念的であるのだ。

\begin{abstract}
An example can be seen in Buddhism's subtle and profound philosophy. In spite of its denial of all form of value, it still insists in the ultimate value of nirvana. In the same vein, the so-called nihilism, while negating all forms of authority, establishes the dictatorship of nothingness itself, which becomes the nihilist's ideal. Also dadaism, while claiming "not to follow any doctrines," follows the doctrine of "not following any doctrines." It is thus that, in the deepest sense, there cannot exist any form of intellectual movement that is not idealist. All "isms" are necessarily conceptual and idealist.
\end{abstract}

Sakutarô's attitude towards Buddhism at this point seems to be somewhat more lenient than the one he assumes towards Naturalism. His characterization of Buddhist philosophy as yügen (幽玄), which translates as "subtle and profound," carries a positive connotation, echoing the aesthetic terminology of Zeami (14th century) in its masterful establishment of Nô poetics. Sakutarô's perception of Buddhism as a "ism" marred by unrestrained idealism, however, suggests the same sort of misunderstanding that took Karatani to identify the existence of a transcendental realm in Japanese culture that would have been overcome somewhere in the third decade of Meiji. Although in his account of the birth of modernity in Japanese literature Karatani does not refer specifically to Buddhism, it seems that both writers assume the existence of a 
life-denying transcendental realm that, under close scrutiny, must at least hold some relation to Buddhism.

What appears to lie at the heart of Sakutarô's and Karatani's assumptions is the lack of regard to the Indian dimension of Japanese culture, or, more precisely, to the original Indian nature of Buddhism. Buddhist scholar Nakamura Hajime (1912-1999) has strongly emphasized the influence of India in the development of Japanese culture. In his essay "Hinduism Influence on Japanese Culture," (1992) Nakamura called attention to the fact that the oldest Indian manuscripts, dating to the first half of the 6th century, are to be found not in India, but in Japan, suggesting a very early transmission. ${ }^{10}$ Such being the case, the lack of scholarly attention to Indian philosophy as an intertextual tool for the analysis of Japanese literary texts calls for reconsideration. Undoubtedly such lack closely relates to the call made by Ramirez-Christensen and presented in the beginning of this essay. Such lack also underpins Sakutarô's misconstruction of nirvana as an idealist concept that envisages the attainment of a transcendental realm. This misconstruction, I contend, lies at the core of the poet's rejection of Buddhism that will be analyzed in detail bellow.

Before we look into Sakutarô's call for the effacement of Buddhism from Japanese literature, however, we should look into a few of his poems that involve Buddhist imagery and scenery. "Shisô wa hitotsu no ishô de aru ka" appears in the fifth section of Aoneko (1923), entitled Shisô to Mûmei (Will and Benightedness). The poem poses an epistemological question involving the figure of the Buddha:

思想は一つの意匠であるか

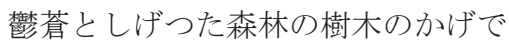

ひとつの思想を歩ませながら

仏は蒼明の自然を感じた

どんな瞑想をもいきいきとさせ

ぞんな涅槃にも溶け入るやうな

そんな美しい月夜をみた。

「思想は一つの意匠であるか」

仏は月影を踏み行きながら

かれのやさしい心にたづねた。

10. See Nakamura, Hajime. "Hinduism Influence on Japanese Culture," Japan Times, Tokyo, January 26, 1992, and also his longer work A History of the Development of Japanese Thought (Tokyo: Kokusai Bunka Shinkokai, 2 vols, 1969, reprinted by Routledge, 1999). 
Shisō wa hitotsu no ishō de aru ka

Ussō to shigetta shinrin no jumoku no kage de

Hitotsu no shisō wo ayumasemagara

Butsu wa sōmei no shizen wo kanjita

Donna meisō wo mo iki iki to sase

Donna nehan ni mo tokehairuyōna

Sonna utsukushii tsukiyo wo mita.

"Shisō wa hitotsu no ishō de aru ka"

Butsu wa tsukikage wo fumiyukinagara

Kare no yasashii kokoro ni tazuneta.

Is a thought the form of a single will?

Wrapped in the arbored dusk of a luxuriant forest

And letting a single thought proceed forward

The Buddha felt the infinite brightness of nature

And witnessed the splendor of the moonlit evening

That brings life to every single though

That melts into the very nirvana.

"Is a thought the form of a single will?"

While crossing the moonlight shadow

The Buddha's gentle heart was visited by a question.

Approaching this piece from the perspective of the transition from bungo-shi ( 文語詩), or the classical form, to kôgo-shi (口語詩), the modern colloquial style, we notice in it a significant influence of Naturalism. Although the poem does secure the sense of romanticism and loftiness advocated by Sakutarô, it also adopts the narrative and descriptive mode of the naturalist aesthetic. The epistemological question posed in the seventh verse together with the physical movement of the Buddha crossing the 
moonlight shadow (tsukikage wo fumiyukinagara 月影を踏み行きながら) produce a sense of naturalness in the poem that was mostly absent from the classical style of from bungo-shi. In the following verses, also from Aoneko, Sakutarô moves into a more critical approach to the figure of the Buddha:

佛陀 或は世界の謎

赫土の多い丘陵地方の

さびしい洞窟の中に眠つてみるひとよ

君は貝でもない 骨でもない 物でもない。

さうして磯草の枯れた砂地に

ふるく錆びついた時計のやうでもないではないか。

ああ 君は「眞理」の影か 幽靈か

いくとせもいくとせもそこに坐つてみる

ふしぎの魚のやうに生きてみる木乃伊よ。

このたへがたくさびしい荒野の涯で

海はかうかうと空に鳴り

大海嘯の遠く押しよせてくるひびきがきこえる。

君の耳はそれを聴くか?

久遠のひと 仏陀よ!

Buddha Aruiwa Sekai no Nazo

Akatsuchi no ooi chūryō chihō no

Sabishii dōkutsu no naka ni netteiru hito yo

Kimi wa kai de mo nai hone de mo nai mono de mo nai

Sōshite isokusa no kareta sunaji ni

Furuku sabitsuita tokei no yō de mo nai de wa nai ka.

Aa kimi wa "shinri" no kage ka yūrei ka

Ikutosemo ikutosemo soko ni suwatte iru

Fushigi no sakana no yō ni ikiteiru miira yo.

Kono taegataku sabishii arano no hate de

Umi wa kōkõ to sora ni nari

Ootsunami no tooku oshiyosetekuru hibiki ga kikoeru. 
Kimi no mimi wa sore wo kiku ka?

Kuon no hito Buddha yo!

Buddha, or the World's Mystery

In the mountainous region of red soil

Inside a lonely cave each and every night

You are not a shell, you are not a bone, you are not a thing

And in the sandy soil of dried seashore weeds

Are you also not something like an old rusted watch?

Ah are you the shadow of truth, or perhaps a ghost?

Year after year just sitting there

Living in a mummy like state like a strange fish.

At the end point of this unbearably desolate wasteland

The sea brightly cries to the open sky

And the distant sounds of onrushing waves are faintly heard.

Can your ears gather those?

Eternal being, oh Buddha!

Here the Buddha seems to have lost contact with reality. His ears appear to no longer gather the sounds of the onrushing waves of the sea that brightly cries to the open sky. Sakutarô's view in this piece draws nearer to his overt rejection of Buddhism. The charge against the Buddha is made in regard to his irredeemable transcendence, which appears to imply the lost connection with reality.

A relevant point in Aoneko is Sakutarô's citation of Schopenhauer in the epigraph to the revised edition of 1923. Schopenhauer's famous catchphrase, "The universe is an expression of the will, and the essence of the will is suffering," is well known as being highly influenced by Hinduism and Buddhism. The irony here lies in the fact that in his rejection of the Buddha's transcendence, Sakutarô finds a more tangible philosophy in Schopenhauer, who in fact was a champion of Indian philosophy during the nineteenth century.

This sends us to the question of Westernization and the development of Japanese modern poetry. In the essay "Shi no Genri kara Mizushima e: Nihon no shi no ongakusei ni tsuite" (From Shi no Genri to Mizushima: On the Musicality of Japanese Poetry), Naitô Takeshi defends the idea that Japanese modern poetry was largely modeled after Western poetry. According to the critic, this situation arose not from a purely formal westernizing 
disposition, but from a substantial demand at the level content that needed to be answered by the employment of new and expanded poetic forms. In Naitô's own words,

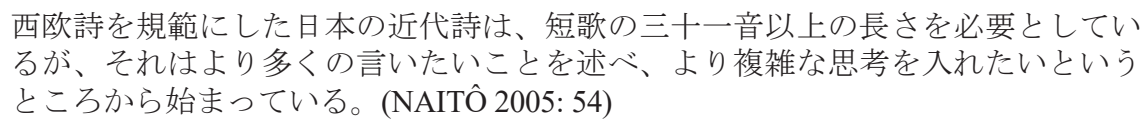

While it was modeled after Western poetry, Japanese modern poetry needed an enlarged form that went beyond the 31 syllables of tanka. And that began because it had more things to say, it needed to include more complex ideas in the poem.

The critic goes on to explain that such demand from content, that is, the necessity of including more complex ideas in the poem, resulted directly in Sakutarô's achievement of the free-colloquial style in Tsuki no hoeru (1917). Although Naitô's appraisal is not entirely wrong, we still need to ask about the content of those ideas that were posing demands of textual enlargement on early modern poets such as Sakutarô. More specifically, we must ask what those "more complex ideas" would be. In order to answer this question, we need to consider not only Sakutarô's philosophical influences, but, most of all, the extent to which such influences were truly Western.

Sakutarô's Western philosophical influences suggest a lingering relation to Buddhism. The poet's well-known Western philosophical influences comprise primarily three thinkers: Schopenhauer, Nietzsche, and Kant. The first we already know as being strongly influenced by Indian philosophy. The second is also valued by Sakutarô for reasons that are actually found in the Buddhist textual tradition, namely his understanding of human suffering (which repeats that of Schopenhauer) and his poetic sense, which, according to Sakutarô, is capable of condensing truth in the form of aphorisms. ${ }^{11}$ The poetic and aphoristic sense, we should note, is also not at all foreign to the Buddhism, as becomes clear when we consider Buddhist sūtra and abhidharma texts.

The third of Sakutarô's acknowledged Western philosophical influences holds an even stronger relation to Buddhist philosophy. The influence of Kant on Sakutarô has been analyzed by Kurihara Hiuma in "Sakutarô Kenkyû - Shisaku no Kiseki Mihappyô Genkô wo Shiza to Shite" (Sakutarô Studies, Tracing Speculative Thought: The Standpoint of the Unpublished Manuscripts). In his analysis of the unpublished manuscripts that appear in the fifteenth volume of Sakutarô's collected works, Chikuma Shobô edition, Kurihara suggests that Sakutarô had in depth knowledge of Kant's philosophy. According to the critic, the poet's synopsis of the first critique's Transcendental Aesthetic and Transcendental Logic found among his unpublished

11. Under Nietzsche's influence, Sakutarô would write his own volume of aphorisms. An appraisal of Sakutarô's understanding of Nietzsche can be gathered directly from the poet's essay "Miscelaneous Impressions on Nietzsche", which appears in the $9^{\text {th }}$ volume of Hagiwara Sakutarō Zenshū, Chikuma Shobō Edition, 1976. 
texts show a sort of clarity and conciseness capable of overshadowing Kant himself (KURIHARA 2005: 106). It is from the German philosopher's understanding of the role of the senses in constructing reality (as the basis for the a priori forms of the sensibility) that Sakutarō develops an epistemology of art based on the concept of kansei (感性, sensibility). As Sakutarô himself explains in the foreword to his Shi no Genri (1928), his work assimilates an early theoretical attempt entitled Geijutsuteki Ninshikiron (An Epistemology of Art), which proposed an the analytical rendering of the aesthetic reason, or biteki risei. Sakutarô justifies his intention by means of a critique of Kant, suggesting that the freedom allowed by the philosopher to practical reason, that is, to the moral realm, should equally be extended to the aesthetic reason, or to the artistic realm.

Our interest here lies in the poet's intense dialog with the Kantian text, and in the strong likeness in content between Kant's and the Buddhist text. Such likeness has been comprehensively analyzed in my work in French entitled Kant et Nāgārjuna: vers la fin de la philosophie comme herméneutique (Paris: L'Harmattan, 2008). As the analysis of this work's argument transcends the scope of this article, it suffices to say that both texts present a skeptical epistemology, from which follows a similar conclusion regarding the possibilities of a moral world. In any case, clarifying the coincidences between the two texts requires a terminological investigation that involves the notions of ontology and metaphysics. In the Kantian text, these notions gravitate around the concept of transcendence, and the failure to grasp them correctly has generated a series of misreadings that plague the field of literary studies. Kant uses the term transcendental to signify an epistemological stance that is incapable of knowing the thing-itself, but that at the same time provides for knowledge of the phenomenal world. Consequently, Kant's transcendental, as in transcendental logic and transcendental aesthetic, does not signify any transcendental realm separated from lived experience. Kant's philosophy is transcendental only in its own terms, and not in the one used, for example, by Karatani as cited above. In this latter sense, both the Kantian and the Buddhist Mahāyāna texts are metaphysical, but not transcendental. Buddhist philosophy is metaphysical in the same sense as Kant's, for it recognizes reality as existing not in the physical objects, but in the mind. It is thus meta-physical. It is also transcendental in the Kantian sense of pointing to reality as separated from exteriorly existing matter, or from what Kant termed the thing-itself, but it is realist in avowing that this separation does not mean total independence. It is finally not transcendental in the religious sense, for it does not posit the existence of a transcendental realm of the general religious sort, the term religion being a Western concept derived from the Latin religare and applied mostly at risk to some forms of Buddhist practice. It is thus that both for Kant and for Buddhist philosophy all ontology is primarily false, for all knowledge is metaphysical. Finally, while Kant's kingdom of ends is actual lived reality perfect by reason, the realization of Buddha nature in the world is also the perfecting of reality made possible by the correct understanding of it, together with corresponding practice (prajñaparāmitā). It is in this overall sense that 
Sakutarô's turn to Kant in his cognitive theory of art can be surmised as equivalent to a turn to the Buddhist Sanskrit tradition.

The similarity between the Kantian and the Buddhist texts, added to Sakutarô's aforementioned interest in Schopenhauer and Nietzsche, shows that what the poet sought in Western philosophy might as well have been looked for in the textual tradition of Buddhism. Or yet, it is possible to conjecture that Sakutarô's turn to the Western philosophers he discussed and praised, was from the start carried out from the perspective of a Buddhist mind. Be it as it may, my point here is that by going inward to the Indian roots of Japanese philosophy and art, Sakutarô would probably have come closer to the philosophical answers he was seeking in regard to notions of perception and aesthetics.

Continuing our analysis of the Buddhist dimension of Sakutarô's poetry, we can now turn to one of his most representative works. Looking at Jimen no soko no byônin no $k a o$ (Face of an ailing man in the bottom of the earth) under the light of the dvādaśangapratityasamutpāda (The twelve-link chain of co-dependent origination, Jp. 十二支縁 起 - 因果論) will show us how this piece represents a highly accomplished example of what I have been calling Buddhist realism:

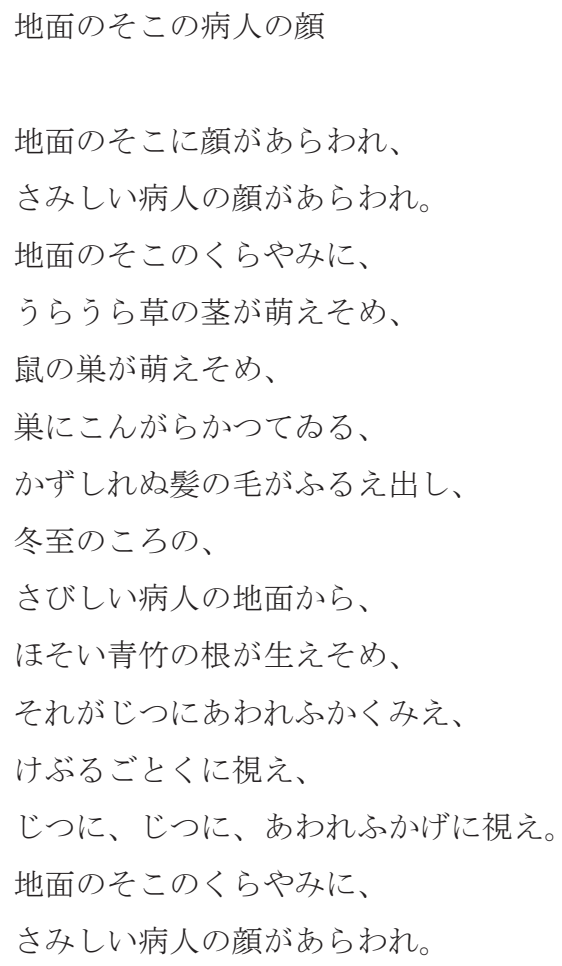


Jimen no soko no byōnin no kao

Jimen no soko ni kao ga araware

Samishii byōnin no kao ga araware.

Jimen no soko no kurayami ni,

Ura ura kusa no kuki ga haesome,

Nezumi no sū ga haesome,

Sū ni kongarakatteiru,

Kazushirenu kami no ke furuedashi,

Tōji no koro no,

Samishii byōnin no jimen kara,

Hosoi aodake no ne ga haesome,

Sore ga jitsu ni aware fukaku mie,

Keburu gotoku ni mie,

Jitsu ni, jitsu ni, aware fukage ni mie,

Jimen no soko no kurayami ni,

Samishī biōnin no kao ga araware.

Face of an ailing man in the bottom of the earth

In the bottom of the earth appears a face,

The face of a lonely ailing man.

In the darkness of the bottom of the earth,

Sprout brightly the shoots of grass,

And sprouts a rat's nest,

Entangled in the nest,

Shiver countless threads of hair,

In the winter solstice,

From the bottom of an ailing man's face,

Sprouts the root of a thin young herb,

And that looks indescribably gloomy,

Like some sort of smoke,

Truly, truly, looking deeply sorrowful. 
In the darkness of bottom of the earth,

Appears the face of a lonely ailing man

Featured in the collection Tsuki ni hoeru (Howling to the Moon, 1917), Jimen no soko no byonin no kao is as an avant-garde piece that transcends generic classification. While Romanticism and the aesthetics of idealism are ruled out from these verses, they do present elements of Naturalism and Surrealism in the lingering images of death and of the rat's nest entangled with human hair, all existing together in the low darkness of the earth. Elements of description, direct perception, and valid cognition operate to establish a picture of despair, or a metaphor for life in general, where solitude and decay turn back and forth into life, as it sprouts again in the form of young stalks of greenery. Appearing in a sequence of interconnected frames, the linked visual elements of such metamorphosis suggest cinematic techniques of camera fading and dissolve typical of early surrealist film (the superposed images remind us of scenes from Luís Buñuel and Teshigahara Hiroshi, or from the earlier avant-garde works of Man Ray).

The gist of the poem lies in the fact that, as they mingle in the basic darkness of the earth, the ailing visage, the rat's nest, and the shivering threads of human hair all become one single reality. This unity suggested in the poem ensues from the all-encompassing perception of a mind that is capable of seeing unity in diversity, or that has transcended discrimination. This mind is capable of understanding the causal relationship between the links that form an existential state of unsurmountable despair: life, sickness and death are all product of the same darkness, and their inter-relation amounts to what Dharmakīrti called vyāpti, or pervasion. At the aesthetic and thematic levels, the poem mingles Naturalism and Buddhism with a strong avant-garde disposition, producing a clear example of Buddhist realism: the cycle formed by the crude images in sequence repeats the Buddhist analysis of causation that generates the cycle of samsāra. The twelve links of this cycle, or the so-called twelve nidānas (Jp. in'nen 因縁) are as follows:
1) avidyā (Jp. Mumyô 無明 ignorance or delusion)
2) samskāra (Jp. gyô 行 mental formations or conceptions)
3) vijñāna (Jp. shiki 識 consciousness)
4) nāmarūpa (Jp. myôshiki 名色 name and form)
5) sadāyatana (Jp. rokusho 六處 the six senses and their organs)
6) sparśa (Jp. soku 觸 contact)
7) vedanā (Jp. ju 受 sensation)
8) tṛṣnā (Jp. katsuai 渇愛 desire)
9) upādāna (Jp. shu 取 attachment) 
10) bhava (Jp. $u$ 有 being or existence)

11) jāti (Jp. shō 生 birth)

12) jarāmarana (Jp. rôshi 老死 old age and death) ${ }^{12}$

Altogether, these links form the cycle of life and death that is defined as samsāra. The circularity of Jimen no soko no byonin no kao, where the first verse is repeated in the end (with a slight modification), thus establishing a sense of eternal return, provides the same idea of endless causation and of endless suffering. Going from birth (in the green stalks) to old age and death (in the ailing face and the shivering hair), Jimen no soko no byōnin no kao can be read as a metaphor for the cycle of samsāra.

Given the strong Buddhist philosophical underpinning of this representative work, we must inquire on the extent and meaning of Sakutarô's call for the rejection of Buddhism that appeared in the journal Chūgai Nippō (中外日報) on September 28, 1934. Sakutarô's article, entitled "Bukkyō to Gendai Bungei" (Buddhism and the Contemporary Literary Arts) has been analyzed by Suga Kunio in Hagiwara Sakutarô - Futatsu no Ronsô ni Miru Bukkyô no Imi (Hagiwara Sakutarō: The Meaning of Buddhism Seen in Two Controversies), ${ }^{13}$ where the critic examines a heated discussion on the theme of Buddhism between Sakutarô and Buddhist scholar Yamabe Shûgaku (1882-1944). Sakutarô's text in Chügai Nippō reads as follows:

\begin{abstract}
明治以来の新しい日本文学は、す心゙て皆日本人的な文学であり、あまりに諦観、 虚淡的、風流的、仏教的な文学ばかりであた。（中略） ゾラや、ツルげネフや、 モーパッサンや、ボードレールや、ドストエフスキィを手本として、彼等のやう に書く [ためには $]$ 彼等西洋の作家と同じやうに、強い人間的熱意によつて人生 を感じたり、考えたり［しなければならず]、日本人の東洋的、仏教的な思潮を 排してキリスト教やヘレニズムに本質してみる西洋思潮を学び、生活の実感上に 洗礼を受け祆ばならない。
\end{abstract}

Since its establishment in the Meiji period, the new Japanese literature has been too traditionally Japanese, and as such excessively resigned, pale, elegant and Buddhistic. (...) In order to write like Zola, Turgenev, Maupassant, Baudelaire and Dostoyevsky, Japanese writers must, like the Europeans, feel and think about life with passion. They must reject their Eastern and Buddhistic intellectual trends, and adopt in their place the Christian and Hellenistic dispositions that constitute the essence of Western thought, receiving thus a sort of baptism of real human feelings.

12. The concept of the twelve nidānas appears already in the earliest texts of the Pāli Canon, notably in the Brahmajāla Sutta of the Dīgha Nikāya (Long Discourses). See Maurice Walshe, The Long Discourses of the Buddha: a Translation of the Dìgha Nikāya (Boston: Wisdom Publications, 1995).

13. Suga's article appears in the periodical Shi to Shisō (Poetry and Thought), 2 (113): 41-46. 
Published in 1934, almost two decades after the 1917 appearance of Tsuki ni Hoeru, Sakutarô's words show a remarkable turn against Buddhism. The poet recognized the depth of Buddhism's influence in Japanese culture, and also the unconscious presence of it in the Japanese intellectual make-up, but disavowed its revival: "Today's re-examination of Buddhism, or of the very Buddhist worldview that has from old penetrated the Japanese sensibility and that is known instinctively and unconsciously to all of us, while its essence is clearly being forgotten at the conscious level, its reexamination has become unfruitful in terms of re-establishing Buddhism as a conscious faith" (SUGA 1994: 43).

Suga points to the times being those of the rise of militarism, poverty and social problems in Japan, with the concurrent and rapid rise of new religions. Although Buddhism is generally understood as distinct from these, the poet's anti-religious sentiment was broad enough to encompass the originally Indian tradition that he himself recognized as being deep-rooted in the Japanese sensibility. In spite of the usages of Buddhism in the rise of Japanese nationalism during the 1930s, which must have played a role in Sakutarô's outright disavowal of it, the poet's main charge has to do his identification of Buddhism with resignation and, at the literary level, with the cause of a pale or dispassionate quality in the artwork. Even acknowledging it as an essential constituent of Japanese culture, the poet asserts that in order to create a new literature in Japan, "as literary artists we must do away with Buddhism" (44)

Sakutarô's perception of Buddhism as a life-denying ideology can be surmised from his theoretical essay on haiku entitled Kyôshû no shijin: Yosa Buson (Yosa Buson, the Poet of Nostalgia, 1933). Here Sakutaro expounds his preference for the poetry of Yosa Buson (1716-1784) instead of that of Matsuo Bashô (1644-1694) on the basis of the youthful vigor of the former in contrast to the weary view of life of the latter. Sakutarô praises Buson by insisting on his modernity, and by constantly comparing the poet from Settsu with the late-nineteenth century Western symbolists. Bashô, on the contrary, is interpreted as frail and as possessing a view of life that hinders the expression of that same passion that was praised in Zola, Turgenev, Maupassant, Baudelaire and Dostoyevsky.

Given that Bashô's poetry is strongly influenced by Buddhism, and that Sakutarô's view of Buson's denies him any Buddhist influence, it would not be mistaken to perceive the grudge against Buddhism as underlying Sakutarô's side-taking between Buson and Bashô. In any case, how much the life-denying and old-weary view of life claimed by Sakutarô to exist in Bashô's poetry entails the idea of a Buddhist transcendental realm to be sought in an after-life is something we must consider. Sakutarô's critique of Bashô, read together with his critique of Buddhism, suggests the possibility of understanding the latter as the core of that very transcendence that ws mentioned by Karatani as having been overcome by the new modernity of Meiji. Undoubtedly Sakutarô's view of Japanese modernity is remarkably akin to that of Karatani's. Sakutarô regards Buddhism as too transcendent, while Karatani perceives a wall of transcendence that was surpassed 
during the third decade of Meiji, right at the event of the birth of Japanese literary modernity. Sakutarô, in the same vein, asserts that Buddhism gets in the way of literary modernity. Both writers perceive modernity in primarily Western terms, denying the possibility of a Japanese modernization that is not modeled after the West.

In spite of the grudge against a Buddhism construed as an imposer of transcendence, looking back at Sakutarô's Jimen no soko no byōnin no kao, with its dark and sorrowful depiction of life and death, we can surmise the unconscious influence of a Buddhist epistemology at play in the poet's grasp of reality. The claim seems to be validated by the poet himself, for has it not been the very Sakutarô who, in "Bukkyō to Gendai Bungei" asserted that the Buddhist worldview "has from old penetrated the Japanese sensibility and is known instinctively and unconsciously to all of us"?

\section{Conclusion}

The stated aim of this essay was to provide a contribution to the analysis of the Buddhist dimension of Japanese poetry, attempting to answer at least in part the demand posed by Ramirez-Christensen in Emptiness and Temporality. In order to that, I started with a discussion of the idea of transcendence posed by Karatani Kôjin in Origins of Modern Japanese Literature, proceeded by looking into the role of Naturalism and its philosophical implications in the establishment of Japanese modern poetry, considered the descriptive aspect of the European movement's compatibility with Buddhist epistemology, pointed to the idea of a Buddhist realism derived from the logic of Dignāga and Dharmakīti, and finally brought the concept of Buddhist realism to bear on the works of Hagiwara Sakutarô. I closed my analysis by pointing to the similar epistemological stance assumed by Sakutarô and Karatani in regard to modernity and to the theme of overcoming transcendence, suggesting that a particular understanding of Buddhism underlies the work both writers. My hope is that the above has dutifully served the originally stated purpose of this essay.

\section{Works Cited}

DUNNE, John D. Foundations of Dharmakīrti's Philosophy. Wisdom Publications, 2004.

HILL, Christopher L. The Travels of Naturalism and the Challenges of a World Literary History. Literature Compass 6/6, p. 1198-1210, 2009.

KARATANI, Kōjin. Origins of Modern Japanese Literature. Duke University Press, 1993.

KURIHARA, Hiuma. Sakutarō Kenkyū • Shisaku no Kiseki - Mihappyō Genkō wo Shiza to Shite. Ekoda Bungaku, Hagiwara Sakutarō Special Edition, 59, vol. 25, No 1, p. 83-155, Summer, 2005. 
MOOKERJEE, Satkari and NAGASAKI, Hojun. The Pramāṇavārtikkam of Dharmakirti: An English Translation of the First Chapter with the Autocommentary and with Elaborate Comments. Nava Nālandā Mahābihāra, 1998.

NAITÔ, Takeshi. Shi no Genri kara Mizushima e Nihon no shi no ongakusei ni tsuite. Ekoda Bungaku, Hagiwara Sakutarō Special Edition, 59, vol. 25, No 1, p. 54-59, Summer, 2005.

NAKAMURA, Hajime. Hinduism Influence on Japanese Culture. Japan Times, Tokyo, January 26, 1992.

NUSSBAUM, Martha. Love's Knowledge. Oxford University Press, 1990.

RAMIREZ-CHRISTENSEN, Esperanza. Emptiness and Temporality: Buddhism and Medieval Japanese Poetics. Stanford University Press, 2008.

STCHERBATSKY, F. Th. Buddhist Logic, Vol. I. New York: Dover, 1962.

HAGIWARA, Sakutarô. Hagiwara Sakutarō Zenshū, vol. 6. Chikuma Shobō, 1975.

SUGA, Kunio. Hagiwara Sakutarō • Futatsu no Ronsō ni Miru Bukkyō no Imi. Shi to Shisô, 1994, 2(113): 41-46.

TOMASI, Massimiliano. The Rise of a New Poetic Form: The Role of Shimamura Hōgetsu in the Creation of Modern Japanese Poetry. Japan Review, 2007, 19: 107-132.

YOSHIMIZU, Chizuko. Defining and Redefining Svalakșaṇa: Dharmakīrti's Concept and its Tibetan Modification. Shoun Hino \& Toshihiro Wada eds. Three Mountains and Seven Rivers: Prof. Musashi Tachikawa's Felicitation Volume. Motilal Banarsidass, 2004. 